\title{
Cultures of Improvement in Scottish Romanticism, 1707-1840
}

\section{Edited by Alex Benchimol and Gerard Lee McKeever}

First published 2018

ISBN: 978-1-138-48293-7 (hbk)

ISBN: 978-1-351-05642-7 (ebk)

9 Medicine and Improvement in the Scots Magazine; and Edinburgh Literary Miscellany (1804-17)

Megan Coyer

(CC BY-NC-ND 4.0)

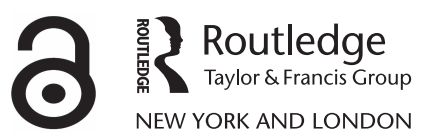


First published 2018

by Routledge

711 Third Avenue, New York, NY 10017

and by Routledge

2 Park Square, Milton Park, Abingdon, Oxon OX14 4RN

Routledge is an imprint of the Taylor \& Francis Group, an informa business

(C) 2018 Taylor \& Francis

The right of the editors to be identified as the authors of the editorial material, and of the authors for their individual chapters, has been asserted in accordance with sections 77 and 78 of the Copyright, Designs and Patents Act 1988.

With the exception of Chapter 9, no part of this book may be reprinted or reproduced or utilised in any form or by any electronic, mechanical, or other means, now known or hereafter invented, including photocopying and recording, or in any information storage or retrieval system, without permission in writing from the publishers.

Chapter 9 of this book is available for free in PDF format as Open Access from the individual product page at www.routledge.com. It has been made available under a Creative Commons AttributionNon Commercial-No Derivatives 4.0 license.

Trademark notice: Product or corporate names may be trademarks or registered trademarks, and are used only for identification and explanation without intent to infringe.

Library of Congress Cataloging-in-Publication Data

Names: Benchimol, Alex, editor. I McKeever, Gerard Lee, editor.

Title: Cultures of improvement in Scottish romanticism, 1707-1840 / edited by Alex Benchimol and Gerard Lee McKeever.

Description: New York : Routledge, 2018. I Series: The enlightenment world ; 32 I Includes bibliographical references and index.

Identifiers: LCCN 2017061769 (print) I LCCN 2018001660 (ebook) I ISBN 9781351056427 I ISBN 9781138482937 (alk. paper)

Subjects: LCSH: English literature-Scottish authors-History and criticism. I Romanticism-Scotland. I Scottish literature-History and criticism. I Scotland-In literature.

Classification: LCC PR8549 (ebook) I LCC PR8549 .C85 2018

(print) I DDC 820.9/14509411—dc23

LC record available at https://lccn.loc.gov/2017061769

ISBN: 978-1-138-48293-7 (hbk)

ISBN: 978-1-351-05642-7 (ebk)

Typeset in Sabon

by Apex CoVantage, LLC 


\title{
9 Medicine and Improvement in the Scots Magazine; and Edinburgh Literary Miscellany (1804-17)
}

\author{
Megan Coyer ${ }^{1}$
}

As Fiona Macdonald notes, 'the Edinburgh Medical School marked the zenith of medical achievement in eighteenth-century Britain' and 'using print and especially the periodical to improve medical practice became a way for practitioners to enhance their professional status'.2 Andrew Duncan, senior (1744-1828) led the way in medical periodical literature, founding and editing both Medical and Philosophical Commentaries (1773-95), 'the first English-language journal of abstracts of books relevant to busy clinicians', and subsequently, with his son, Andrew Duncan, junior (1773-1832), Annals of Medicine (1796-1804). Duncan, junior was also editor and founder of the Edinburgh Medical and Surgical Journal in $1805 .{ }^{3}$ However, the initiative for which Duncan, senior is best remembered, the campaign for the establishment of the Edinburgh Lunatic Asylum, required that he reach a wider, popular audience. In this chapter I examine how Archibald Constable's Scots Magazine; and Edinburgh Literary Miscellany (1804-17) became a medium for the promotion of key medical initiatives in early nineteenth-century Edinburgh, including the campaign for the Edinburgh Lunatic Asylum, but also other medico-philanthropic endeavours directed towards improving health in Scotland.

The omnipresence of science and medicine in the nineteenth-century popular periodical press is becoming increasingly recognized, as scholars have responded to a perceived neglect of 'the extent to which scientific controversies of the nineteenth century were conducted in, or extended to, semi-popular scientific journals and generalist periodicals. ${ }^{4}$ This shift is of particular relevance to the Edinburgh context, as while the integral relationship between specialist medical periodicals (and medical publishing more broadly) and the success of Edinburgh medicine is acknowledged, less attention has been paid to the role of the popular periodical press. The medical contents of the Scots Magazine are, for example, a largely untapped resource. My own recent work on medical contributors to the Edinburgh Review and Blackwood's Edinburgh Magazine in the early nineteenth century argues that:

The politicized popular periodical press played a key role in shaping medical discourse during this period, as those authors who turned to 
periodicals, such as the Edinburgh Review or Blackwood's, were read within (and also frequently drew upon) their distinctive ideological contexts, utilized their stylistic conventions, and built upon previous articles. $^{5}$

In brief, the Edinburgh Review promoted a progressive medico-scientific culture, associated with 'the march of intellect', via at times scathing reviews of medical and physiological texts, contributed by key medical figures such as Duncan, junior, John Thomson (1765-1846), and John Gordon (1786-1818), who drew upon and contributed to the liberal Whig ideology and reforming rhetoric of the Edinburgh Review. Blackwood's, in contrast, through its 'distinctive Romantic ideology and experimental form enabled the development of an overtly "literary" and humanistic popular medical culture, which participated in a wider critique of liberal Whig ideology in post-Enlightenment Scotland'. ${ }^{6}$ While Blackwood's was by no means 'anti-medical' in any straightforward sense, the magazine was at times critical of progressive medico-scientific culture and its perceived association with Whig ideology, and through hybrid medicoliterary reviews, discursive essays and 'medico-popular' fiction promoted an ideal of the gentlemanly, medico-literary 'man of feeling' and a distinctively Tory social medicine. As such, the ideological framing and stylistic innovations of each shapes medical discourse within the periodical. In this chapter I consider what this approach might reveal about the relationship of the Scots Magazine to medical culture-the magazine which may be seen as the third major player in popular periodical culture in Romanticera Scotland. In doing so, I respond, in part, to an overarching neglect of the medical faculty at the University of Edinburgh (founded in 1726) and the proliferation of medical clubs, societies and institutions that thrived during the eighteenth and early nineteenth centuries by scholars of Scottish Romanticism in their conceptualizations of the national public sphere and Scottish national identity, ${ }^{7}$ despite the wealth of historical scholarship on the centrality of medicine and science to the Scottish Enlightenment. ${ }^{8}$ Turning to the Scots Magazine in the first decades of the nineteenth century, we see medical men participating in this national public sphere and medicine's discursive role within a periodical which promoted the national culture of improvement deemed by the editors of this volume to be central to the dynamic formation of Scottish Romanticism across the long eighteenth century.

The Scots is often dismissed as the stale magazine-the 'dotard' in the words of Henry Cockburn-that Blackwood's stylistically defined itself against. Yet as David Stewart notes, 'the image of the Scots as an amusing relic that lived beyond its time needs reappraisal'. ${ }^{9}$ The conductors of the first series of the Scots Magazine (launched in 1739) explain in the inaugural issue that their new magazine builds upon the recent success of 
both the Gentleman's Magazine and the London Magazine (upon which the Scots was modelled), but is intended to address the complaint that 'our distance from the place of their publication [renders] their contents stale before they come to hand', and to specifically serve 'the interest of Scotland' by 'reviv[ing] that universal esteem which SCOTLAND so justly acquir'd amongst her neighbours by the valour and learning of our ancestors'. ${ }^{10}$ Alex Benchimol has recently drawn attention to the role of the first series in projecting 'Scottish material and cultural improvement as a compelling national narrative to its readers', ${ }^{11}$ and Stewart similarly describes how 'the magazine helped cultivate in its readers a sense of themselves as a community engaged in precisely the scene of Enlightenment "improvement" celebrated by many historians of the periodical'. ${ }^{12}$ Benchimol particularly highlights a report detailing the progress of the construction of Edinburgh's Royal Infirmary within the 'Domestic Occurrences' section of the inaugural issue as most clearly reflecting this 'emphasis on Scotland's material and cultural improvement'. ${ }^{13}$ As we will see, medical institutions and initiatives continue to feature within the magazine in the first decades of the nineteenth century, and while a stress on improvement continues to shape the magazine's contents-including its medical contents-by this point confidence in Scottish improvement was tempered in the magazine, as contributors responded to the new socio-cultural conditions of the early nineteenth century, including the particular challenges brought on by an intensified period of industrialization.

Archibald Constable took over the magazine in 1802, merging it with the Edinburgh Magazine in 1804, and David Stuart M. Imrie observes that "the general impression created by a study of the volumes between 1804 and 1816 is that the magazine had "gone back." It stood for utility rather than entertainment: in spirit it resembled its first series which ended in 1793. ${ }^{14}$ This chapter focuses in on this period for the Scots Magazine, prior to its re-launch in 1817 as the Edinburgh Magazine and Literary Miscellany (designed to compete with Blackwood's). It examines the magazine's continued 'emphasis on Scotland's material and cultural improvement' in the first decades of the nineteenth century and considers the way in which Scottish medicine (and particularly the Edinburgh medical school) and Scottish medical men become ideal exemplars of a culture of improvement (through, for example, biographies of medical men) and emblems of national pride, and how this created a favourable context for the promotion of national medical initiatives in the magazine, which are particularly linked to the rising field of 'medical police' (the forerunner of public health). By examining the magazine's medical contents and considering medicine's place within the broader ideological framing of the magazine, I hope to shed further light on the relationship between Edinburgh's thriving popular periodical culture and Scottish medicine in the early nineteenth century. 


\section{Megan Coyer}

\section{The Culture of Improvement and Medical Initiatives in the New Series}

In June 1809 a contributor to the Scots declares that 'IT is with feeling of great satisfaction that we occasionally observe, in the periodical work under your superintendence, hints and suggestions for the improvement of this city'. ${ }^{15}$ By March 1814 one contributor is concerned that the annals of the Napoleonic wars has marginalized the magazine's dedication to civic and national improvement and expresses a desire to see 'this Journal, which has for many years been the register of noble deeds performed in war, . . . attempt to excite attention and emulation as to great improvements in peace' ${ }^{16}$ However, the emphasis on improvement in the early Scots Magazine clearly continued following its re-launch in 1804 as the Scots Magazine; and Edinburgh Literary Miscellany. The longevity of the series, 'Memoirs of the Progress of Manufactures, Chemistry, Science, and the Fine Arts', which ran from 1804 through 1817, tracking the 'endless process of alteration and transformation' intrinsic to the Enlightenment 'culture of improvement', is perhaps a case in point. ${ }^{17}$ Other series, such as 'Account of Improvements and New Institutions throughout Scotland', launched in September 1814, were more short-lived, but these were complemented by singular articles highlighting improvements in civic infrastructure and governance, including: 'On the Improvements and Public Buildings of Edinburgh' (March 1805), 'Account of Recent Improvements in Glasgow' (April 1811), 'Plan for the Improvement of the Edinburgh Markets' (July 1811), 'Thoughts on the Improvement of the Police of Edinburgh' (February 1812), 'Account of Improvements carried on in the Country of CAITHNESS in the year 1803' (November 1812), and 'Hints for improving the Public Market-Place in the Town of LEITH, \&c.-With a Plan' (May 1814). At the same time, the importance of a dedication to moral improvement was emphasized in Addisonian essays, such as those by 'The Observer', which featured in most numbers between December 1809 and March 1811 and heralded the delights of 'the inward consciousness of a daily progress in the path of intellectual and moral improvement'. ${ }^{18}$

From its re-launch, the particular form of the Scots Magazine was perceived to be a catalyst to the culture of improvement. Within the inaugural number in January 1804, a piece on 'Queries, Inquiries, and Hints' outlines the utility of the magazine form:

IF I rightly conceive the nature and project object of a Magazine; it should rather contain such short notices and hints as will lead to regular and systematic inquiry. . . . It ought to furnish the materials for investigation and study; and to be considered as the repository for occasional remarks, and the medium thro' which doubts may be solved and inquiries directed. ${ }^{19}$ 
This striking declaration of the magazine's presumed empirical, utilitarian function (a stark contrast to Blackwood's later emphasis on entertainment and the Edinburgh Review's emphasis on cultural critique) is aptly illustrated by a piece within the same number on 'On Rural Police as it Respects the Building of Villages'. This communicates a brief proposal for improving the 'situation and construction of country villages in Scotland', directed towards 'the attention of the country gentlemen in Scotland and the opulent manufacturers, who may be engaged for national benefit and private emolument, in schemes of improvement'. ${ }^{20}$ The contributor laments that 'with all the improvements in works of art or science of which we have to boast, in the subject now under consideration there has been a systematic and deliberate degeneracy,' situating their suggestions for promoting the 'cleanliness' of villages and removing 'filth of every kind' within a developing discursive strand in the magazine identifying a lack of cleanliness, in particular, as a moral and material blight on an otherwise improved Scottish society. ${ }^{21}$

In March 1804 the first of a three-part series of articles on 'Female Schools for Cleanliness, Morals, and Decorum' opens with a reflection on the remit of the Scots Magazine:

IT is with much satisfaction I perceive a new system adopted by you in conducting a literary periodical work, which formerly obtained a considerable share of public approbation, and which, if judiciously arranged, is unquestionably well calculated to convey, not only pleasure, but instructive information to the general reader. ${ }^{22}$

However, 'A Cleanly Scotsman' is clearly more concerned with purveying 'instructive information' when he laments the present inability of Scotsmen to attend to long moral essays and praises the magazine's plan 'of inserting short and pertinent queries, to catch attention to subjects of national utility' as 'the best calculated to awaken observation, and call forth the serious consideration of such as may be instructed in the different objects to which they allude'. ${ }^{23}$ Focusing upon the ability of cleanliness (and particularly female cleanliness) 'to improve, civilize, and refine national character', he critiques 'the increasing vice and disorder of our luxurious capital'-resulting from rapid advancements in 'manufactures, agriculture, and trade'-and views a lack of cleanliness, particularly amongst the lower orders, as a threat to not only material, but also moral improvement, declaring:

Without those pleasurable sensations, arising from conscious purity and a consequent disgust at what is offensively filthy, I maintain, that a proper purity of mind cannot possibly exist; and that, with all the external symptoms of improved society, a concealed, radical disease, lurks and rankles in the moral system, to the injury of its perfect health, vigour, and energy. ${ }^{24}$ 
His argument is complemented the following month by a piece 'On the Causes and Consequences of Inattention to Cleanliness', which sets out to prove 'that a want of attention to purity, is apparent on the very face of things in this your celebrated city' and provides suggestions, primarily for the regulation of servants, intended to enable 'Edinburgh and Scotland [to] make swift advances to that state of decency and purity in their internal and external policy which the improved state of society so loudly demands'. ${ }^{25}$

This discursive strand in the magazine reflects a fundamental concern with social order in Scotland at this time, as rapid industrialization, particularly in mining and textile manufacturing, led to population growth in small villages and towns that outpaced the ability to provide proper 'living space or sanitary provision'. ${ }^{26}$ Brenda White, in her examination of the socio-cultural conditions that enabled the field of 'medical police' (what we would today refer to as public health) to flourish in early nineteenth-century Scotland, highlights these widespread concerns, which also led to the Police Act in Edinburgh in 1805. This act included provisions for maintaining street hygiene, as the term 'police' was interpreted in the eighteenth-century French sense 'to describe regulatory functions of local government'. ${ }^{27}$ 'A Cleanly Scotsman' uses 'police' in this sense when he decries that:

After a long lapse of 30 years, without any proper police in Edinburgh, and after much apathy and delay, we are now, is it said, about applying seriously for some provision against the increasing vice and disorder of our luxurious capital. ${ }^{28}$

As M. McCrae indicates, in the late eighteenth century, this urban crisis was a primary inspiration for Duncan, senior, in his championing of the field of medical police, as the:

cycle of disease, physical degradation and death was perhaps at its most obvious in Edinburgh, 'the dirtiest town in Britain in the eighteenth century,' which had also doubled in population in one lifetime. To reformers, like Duncan it had become an affront to an 'Enlightened' and humanitarian society. ${ }^{29}$

This crisis was also, partly, the impetus behind the building of the city's New Town, begun in the 1760s but not completed until the mid-nineteenth century.

Several medical articles in the Scots Magazine at this time, including those on the Edinburgh Lunatic Asylum, are related to the rising interest in the emergent field of medical police (one of the most innovative contemporary areas of Scottish medicine), and a brief introduction to this field in Scotland will be useful at this point. Duncan, senior began introducing lectures on medical police and medical jurisprudence (the forerunner to forensic medicine) at Edinburgh from 1790 when he became Professor of the Institutes 
of Medicine, and in 1798 he presented a proposal before the Town Council on the necessity of a Chair in Medical Jurisprudence and Medical Police, which was unsuccessful. ${ }^{30}$ The proposal did not come to fruition until 1806, when during the short period of Whig governance known as the 'Ministry of All the Talents' (1806-7), the Lord Advocate Henry Erskine, Duncan's longtime friend, realizing 'the ultimate value of inserting medical knowledge into the delicate balancing mechanism of the new social order' following the American and French revolutions, supported his cause, much to the chagrin of the conservative medical faculty at Edinburgh at this time. ${ }^{31}$ As McCrae indicates, 'Duncan was among the first of the medical profession in Britain to be convinced that the profession had a duty to promote the health of the people', and in this recognition, he followed the lead of continental physicians, such as Johann Peter Frank (1745-1821), 'the leading advocate of a policy for the improvement of the health of the body of the populace' in the German-speaking world, as well as radical reformers in France who called for 'massive intervention by the state in the medical care of the individual'. ${ }^{32}$ However, 'Duncan's version of medical police replaced state intervention with a system based on private philanthropy'. ${ }^{33}$ Infusing the continental concept of medical police with the liberal individualism and civic humanism of the Scottish Enlightenment, Duncan along with his son, who would become the first Professor of Medical Jurisprudence and Police at Edinburgh in $1807,{ }^{34}$ preferred persuasion, private philanthropy and 'the efforts of local communities' ${ }^{35}$ Duncan addressed sanitary issues in his Heads of Lectures on Medical Police (1801) and in his memorial to the Town Council in 1798 (which included headers such as 'CLEANLINESS' and 'THE SITUATION OF HOUSES AND PLACES OF ABODE' in a list of what 'MEDICAL POLICE RELATES TO'). ${ }^{36}$ Yet in contrast to the later English model of public health, famously spearheaded by Edwin Chadwick and dominated by sanitary reform, as White indicates, 'sanitary measures were far less important to [Duncan] than the individual care of the sick poor through a system of specialized hospitals and dispensaries, for whose construction and management he gave detailed instructions' ${ }^{37}$

In his campaigns for these institutions specifically, and for the importance of medical police more broadly, Duncan, senior drew upon a rhetoric of improvement and national pride well suited to the ideological context of the Scots Magazine. For example, in his memorial to the Edinburgh Town Council in 1798, he declares:

If the principles of Medical Police were separated from the professional part of medicine, and communicated in a form generally intelligible, in what country have we reason to expect more beneficial effects from its influence, than in this? Where is the spirit of patriotism and benevolence so prevalent? What nation is more generous in its public institutions? Where does the individual sacrifice a part of his wealth so willingly for the benefit of the community? It seems only necessary to prove that 
an undertaking will be of advantage to the State, to have it carried into instant execution. But, can medical knowledge be more usefully employed, than in pointing out the means of preserving or improving health; of supplying healthy nourishment to the poor, especially in times of scarcity; of opposing the introduction of contagious diseases, and of checking their progress; of securing to the indigent the advantages intended by their benefactors; or rearing the orphan to the support of the nation which has adopted him; and of diminishing the horrors of confinement to the poor maniac and the criminal? ${ }^{38}$

Duncan, in fact, considered medical police to be 'of incomparably greater consequence, and more widely extended influence' than medical jurisprudence as 'it regards not merely the welfare of individuals, but the prosperity and security of nations' ${ }^{39}$ The philanthropic ethos of his version of medical police necessitated popular forums, such as the Scots Magazine, through which to communicate this importance 'in a form generally intelligible' and thus to raise money through subscriptions.

In April 1804-the same issue of the Scots that contains the second article on 'Female Schools for Cleanliness, Morals, and Decorum'-two medical articles are introduced as follows:

The following two papers, on subjects highly interesting to the community (which our readers will perceive were written some time ago, and the one at a considerable interval of time from the other) we have received from a Gentleman, whose professional skill and knowledge qualify him to be a proper judge of the necessity of the establishments which he recommends. ${ }^{40}$

The first is entitled, 'On the Necessity of a Public Lunatic Asylum in Edinburgh' and the second, 'On the Establishment of a Lock Hospital in Edinburgh'. From the editorial introduction, it is clear the papers are written by a medical practitioner. Duncan began his campaign for the establishment of a public lunatic asylum in Edinburgh in 1790, when he became President of the Royal College of Physicians of Edinburgh (RCPE) and formed a committee, which put forward a series of recommendations in August $1791 .{ }^{41}$ Duncan's plan, as outlined in later writings, that fees paid by wealthier patients offset the costs of caring for 'pauper lunatics', is forwarded in the Scots Magazine article in 1804, at which point the campaign was at a low ebb. While the RCPE approved the recommendations, and a public appeal was launched by the Lord Provost in 1792 with the support of many civic dignitaries and both the RCPE and the Royal College of Surgeons, 'by 180614 years after its initiation-there had been only 21 subscribers contributing a total of about $£ 223,{ }^{42}$ As such, it is unsurprising that the article, which is dated 'May 2 1801', proposes further ways of gaining subscriptions from the public: the article calls for a 'popular clergyman' to: 
give a sermon in favour and support of this infant charity. The receipts at the church doors will at least pay for printing the sermon, with an appendix, explaining the views of the managers. Let the sermon and history be sold or circulated gratis to induce subscriptions. ${ }^{43}$

The article's placement within a popular periodical performs a similar task as the proposed sermon, albeit without the religious authority of a 'popular clergyman'. However, in context of the Scots Magazine, beyond appealing to the general emphasis on civic and national improvement in the magazine, the article builds upon the discursive strand concerning the 'increasing vice and disorder of our luxurious capital'. ${ }^{44}$ It laments that:

INSANITY has rapidly increased of late years all over our Island, from dissipation, irregular hours, the baneful effects of the gaming table, \&c. \&c. in the higher classes, and the no less pernicious use of ardent spirits, tea, and other enervating habits, amongst the inferior orders of men. ${ }^{45}$

'On the Establishment of a Lock Hospital in Edinburgh', while amplifying the call for a public lunatic asylum, also mirrors the concurrent series 'Female Schools for Cleanliness, Morals, and Decorum' in its focus on the female sex as the site of (literal and figurative) public contagion and therefore the target of reform, while more broadly appealing to the magazine's concern for what the author terms the 'national good' ${ }^{46} \mathrm{~A}$ few months later, an article simply signed 'A' more overtly appeals to national pride in appealing for public financial support for the Edinburgh Royal Infirmary: 'IT is certainly not very honourable to the Scotch nation, that they will not (for I cannot doubt their power,) support, in a regular and proper manner, the Royal Infirmary of Edinburgh. ${ }^{47}$

Duncan's campaign for a public lunatic asylum gained substantial ground in 1806, when Henry Erskine, with his brother Thomas (Lord Chancellor) and Sir John Sinclair, obtained 'a grant of $£ 2000$ from the Jacobite estates forfeited after the '45 rebellion', and the following year a Royal charter for the establishment of the charitable institution was granted. ${ }^{48}$ However, further funds were needed, and a new public appeal was launched from 1807, in which the Scots Magazine played a key role. Two articles were published in the magazine, which were also published in pamphlet form: 'Address to the Public, respecting the Establishment of a Lunatic Asylum at Edinburgh', which featured in the Scots in November 1807, and 'Some Account of the Plan for establishing a Lunatic Asylum at Edinburgh', which appeared in the January 1808 number. These were published together, along with a 'Copy of his Majesty's Warrant Erecting the Contributors to the Edinburgh Lunatic Asylum into a Body Corporate' and a series of plates of architectural plans 'Engraved by Kirkwood \& Sons Edinr' in the pamphlet, 'Address to the Public, Respecting the Establishment of a Lunatic Asylum at Edinburgh', 
printed by James Ballantyne and Co. in 1807 . According to Chalmers, this pamphlet was 'undoubtedly compiled and partly written by Duncan' as part of the fund-raising appeal. ${ }^{49}$ Both articles were later included as appendices to Observations on the structure of hospitals for the treatment of lunatics, and on the general principles on which the cure of insanity may be most successfully conducted. To which is annexed, an account of the intended establishment of a lunatic asylum at Edinburgh. Illustrated by Five Engravings (1809),,$^{50}$ and the review of this text for the Scots Magazine in January 1810 notes the magazine's involvement in the campaign:

WE have already taken repeated opportunities of introducing this establishment to the notice of our readers. In our number for November 1807, we inserted an Address to the public, issued when the project was first set on foot. In January 1808, we communicated a statement of the Plan, which had then been matured, and for the promotion of which, the sum of two thousand pounds had been obtained from the forfeited estates.-The undertaking was carried forward so rapidly by the zeal of those engaged in it, that in March following, we were enabled to present our readers with the engraved plans of the building intended to be erected for this useful purpose. These different documents are here reprinted, along with others equally important, and of greater extent, forming a complete view of the system to be adopted. ${ }^{51}$

The engraved plans to which this review refers featured as a frontispiece to the magazine, along with a short 'Description of the Plan of the Edinburgh Lunatic Asylum' in March 1808..$^{52}$

From its re-launch in January 1804, each issue of the magazine featured a frontispiece engraving depicting 'some of the most beautiful and interesting Views which Scotland can present; and portraits of the most eminent Scottish Characters, which have either never before been presented to the public, or have been executed in a very inferior manner', and the engraved plans of the Lunatic Asylum appear to have been specially commissioned for the Scots. ${ }^{53}$ The engravings, like most featured in the Scots at this time, are by Robert Scott (1777-1841), and the 'SKETCH SHEWING THE RANGE OF BUILDINGS WHICH FORM ONE SIDE OF THE SQUARE', in particular, is more aesthetically rendered than the same view rendered by Kirkwood \& Sons, in its inclusion of a pastoral foreground of grass lawns and a background of clouds framing the buildings. In depicting the Edinburgh Lunatic Asylum in a manner similar to 'the Scottish country seats' typically rendered by Scott for the magazine, ${ }^{54}$ readers are encouraged to imbue the projected asylum with the same national pride as 'some of the most beautiful and interesting Views which Scotland can present'. Duncan later included the Scott engravings (with a credit to the Scots Magazine) in his Short Account of the Rise, Progress, and Present State of the Lunatic Asylum at Edinburgh, with some remarks on the general treatment of lunatics, pointing out the 
advantages of avoiding all severity. To which is annexed, a complete list of the contributions received, whether from towns, parishes, or individuals, for erecting a proper building for the cure of insanity in the metropolis of Scotland (1812).55

Roy Porter has indicated that the Gentleman's Magazine included information about medical initiatives and assisted in the collection of subscriptions, as part of the 'voluntary hospital movement' in Georgian England up until the 1810s. ${ }^{56}$ As such, in its involvement in the campaign for the Edinburgh Lunatic Asylum, the Scots Magazine was following in an established magazine tradition within Britain. Further, the nationalistic rhetoric utilized in the Scots is also present, albeit to a lesser extent, in the Gentleman's. For example, in February 1805, one correspondent writes:

THE very great encouragement which the Asylum for the Deaf and Dumb, under the patronage of the Marquis of Buckingham, has received, reflects the highest honour on the British character, and displays that benevolence, which, to excite its most active exertions, needs to be informed of objects of distress, and practical means of relief. ${ }^{57}$

The key difference is that the nationalistic rhetoric in the Scots is directed towards the Scottish rather than the wider British nation and often explicitly represented the magazine's continued dedication to 'Scottish material and cultural improvement'. For example, in June 1810, an article on 'Observations Respecting Lunatic Asylums in Scotland' is prefaced with a letter to the publisher, by 'A Scot', declaring that 'By inserting in your periodical work, which has long had the credit of tending to support both the honour and the interest of the nation, the following observations on Lunatic Asylums, you may do some benefit to the public'. ${ }^{58}$ Similarly, in April 1812 in detailing a 'View of the Institution at Edinburgh for the Relief of Incurables', a correspondent insists that 'your Magazine ought to contain a record of a Scotch establishment, so evidently beneficial as the present'. ${ }^{59}$ Additionally, the sheer extent to which the Scots Magazine was involved in the campaign for the Edinburgh Lunatic Asylum is notable, and I would like to suggest in the remainder of this chapter that this involvement is indicative both of the symbolic power of Scottish medicine for a magazine dedicated to promoting a culture of improvement, as well as the importance of the magazine during this period as a public forum for promoting and displaying what Michael Brown has termed 'medico-gentility'.

\section{Scottish Medicine and 'Medico-Gentility' in the Scots Magazine}

In the first decades of the nineteenth century, Edinburgh was still the capital of medical teaching in Britain. ${ }^{60}$ The Scots Magazine radiates pride for an institution that garnered international recognition for the cultural and 


\section{Megan Coyer}

intellectual achievement of Enlightenment Scotland, containing numerous references to 'that celebrated seat of learning', 'that great seminary of medical learning', and 'our renowned medical school' ${ }^{61}$ One contributor in May 1807 notes that 'Edinburgh has, it seems, among strangers, acquired some degree of fame for what is called its medical school' only to declare that 'for my part, I take this opportunity of declaring publickly, and let them make their best of it, that none of the regular practitioners, as they are called, in town, ever did me the smallest service' ${ }^{62}$ However, the article, humorously signed 'Timothy Stiffrump', is a satire, glorifying the powers of patent medicines to such ludicrous extremes that such fringe practices are discredited in favour of the 'regular practitioners' of Edinburgh. A four-part article, 'Description of Edinburgh: with an Account of the present State of its Medical School', which featured from December 1808 through April 1809 and comprised a series of translated letters from the German of Johann Peter Frank, is perhaps the most sustained tribute to Edinburgh medicine in the Scots Magazine at this period, and Frank also discusses the state of Glasgow medicine in a concluding letter featured in May 1809. ${ }^{63}$ Unsurprisingly, due to his own renown in the field of medical police, Frank records his favourable impressions of charitable establishments, such as the public dispensary founded by Duncan, senior, alongside his opinion of the University of Edinburgh 'not only as the foremost in Britain, but also as one of the first in Europe', while also providing suggestions for further improving teaching and appointing practices and public provisions ${ }^{64}$ However, medical biographies provide the most consistent source of coverage for Scottish medicine in the Scots during this period.

Roy Porter notes the increasing prevalence of medical biography in the Gentleman's Magazine in the first part of the nineteenth century and postulates that this is part of the growth of professional (rather than lay) medical authority at this time. As readers became less active participants in the medical world from the 1810s, indicated by 'a dramatic decline in the exchange of medical advice, inquiries, remedies' in the magazine, 'idealized accounts of prominent physicians' careers began to appear in the obituary columns' ${ }^{65}$ The Scots Magazine does directly re-print at least one medical biography from the Gentleman's Magazine (that of Dr David Pitcairn (1748-1809) in August 1809), but the Scots is unique in its exclusive focus on Scottish medical men (or those with at least some Scottish connection), providing a public forum for the expression of a national medical identity. The biographies featured are primarily those of recently deceased medical men, but accounts of Scottish practitioners of historical importance are also included. In considering the discursive function of these medical biographies in the Scots in relation to the magazine's overarching focus on 'Scottish material and cultural improvement', it is useful to turn to the magazine's own reflections on biography as a genre.

In March 1804, an article 'On Biography' praises the genre's combination of 'instruction and entertainment' and particularly highlights it as a 
catalyst for moral and intellectual improvement, noting that 'the powers of our mind are called forth and improved by our desire and our attempts to trace to their proper causes, those talents or virtues which constituted him great and respectable'. ${ }^{66}$ While those 'ignorant of world' can be impressed with 'a conviction of the superior happiness of virtue' by reading biography, the philosopher gains insight into human nature. ${ }^{67}$ As such:

If the life of the man of science be faithfully and fully narrated, we can trace every step by which he advanced, mark every obstacle which impeded his progress, and witness every hope which animated his bosom. We are thus furnished both with the means of imitating him, and of increasing our knowledge of human nature. ${ }^{68}$

The particular emphasis on the 'life of the man of science' is notable, and in tracing the lives and careers of medical men the Scots Magazine provides ideal exemplars of lives dedicated to a culture of improvement-both moral and practical.

Beyond his contributions to therapeutics (and his discoveries relating to the treatment of fever with cold water, in particular), Dr James Currie (1756-1805) is praised as 'a zealous and active supporter' of 'every plan for promoting liberal studies and the improvement of the human mind'. The biographer traces his success in establishing himself both in his profession and in contributing to the 'ornamental parts of literature' (most famously through his edition of the works of Robert Burns, which included an influential biography), while highlighting his characteristic support for 'all his young [Scottish] countrymen', which gained him notable esteem. ${ }^{69}$ Dr James Anderson (1738-1809), who served as a surgeon in the East India Company and went on to become physician-general in Madras, is celebrated for the 'warmth and benevolence of his heart, and energy of his mind' and his steadfast dedication to 'whatever could benefit his species', which included a range of horticultural activities. ${ }^{70}$ The Edinburgh-trained surgeon and botanist, Dr William Roxburgh (1751-1815) is presented as 'a man of clear, distinguishing, powerful intellect, born with an uncommon portion of native good sense, which he improved by study and profound reflection', whose 'loss will be lamented by all those who feel the value of great abilities devoted to useful purposes. ${ }^{71}$

A particularly notable example is the 'Memoirs of the Late Sir Andrew Balfour', a seventeenth-century virtuoso physician whose 'whole life seems to have been a series of public and private offices to God, to his king, to his country, and his friends'. ${ }^{72}$ After detailing how his love of botany led to a study of physic and his extensive European travels laid the foundations for his medical career, the hagiographical account notes his contributions to the improvement of Scottish medicine: upon his return to Scotland, 'he first introduced into Scotland the dissection of the human body; and may thereby be considered, as having laid the foundation of any honour, that this 
country may have since acquired in medicine'. ${ }^{73}$ In Edinburgh he founded a botanical garden, played a leading role in founding the Royal College of Physicians of Edinburgh, 'that institution, which has ever since been so useful and ornamental to his country', and 'not long before his death, his desire to advance the science of medicine in his native country, joined to the humanity of his disposition, led him to project an hospital in the city of Edinburgh' (which would eventually become the Royal Infirmary). ${ }^{74}$ The biography concludes with a reflection on his wide-ranging accomplishments and virtuous character:

To the character of the most eminent physician in this country, we find added, those of a consummate scholar, of an able philosopher, of an accomplished gentleman, and of a patriotic and beneficent citizen:- A group of qualifications, which to my view at least, forms one of the most respectable characters in human life. ${ }^{75}$

While this character description is that of a seventeenth-century physician, it identifies Balfour as successfully participating in what Michael Brown terms a culture of 'medico-gentility'-'a culture of medicine in which identity and social performance were structured by aspirations to gentility and were framed by the values of politeness, sociability and civic engagement'. This, according to Brown, continued to inform medical identities until at least 1815 (by which point medical identities began to be shaped primarily by 'expertise, professional self-identification and a political engagement with the care of the social body'). ${ }^{76}$ Brown develops the term 'medico-gentility' in his study of York medical culture, but it is of particular relevance to the Scottish medical context, where:

Forging a successful career in medicine was not only dependent on practical therapeutic and research skills, but also on the ability to display the trappings of a polite, humane gentleman in possession of a liberal education, evidenced by a taste for art and literature. ${ }^{77}$

Such an ability to display the 'ornamental acquisitions' was famously discussed by John Gregory (1724-73) in his Edinburgh lectures. ${ }^{78}$ Unsurprisingly then, the medical practitioners whose lives are deemed sufficiently notable to feature in the Scots gained renown in part due to what might be viewed as extra-professional pursuits and by exhibiting the values of 'politeness, sociability and civic engagement'. As such, these medical biographies cyclically reinforce the values of 'medico-gentility' in the Scottish context, while the Scots itself functions as site to publicly perform this medical identity.

One example of such a performance is 'Lines to Dr Currie, On his valuable Discoveries relative to the effect of cold water in Fevers', which is published 
in the 'Poetry' section of the February 1805 number. The poem, simply signed 'Edinburgh. W', is prefaced with a letter 'To the Editor', explaining the inspiration for the verses:

As I am a student of medicine, I naturally feel deeply interested in every improvement in the science which is calculated to diffuse blessings among mankind, and to alleviate the most common and fatal disease, to which humanity is incident, viz. Fever-Nothing, in my opinion, has tended so much to disarm fever of its mortality as the liberal use of cold water, both internally and externally, as recommended by the celebrated Dr Currie of Liverpool. ${ }^{79}$

While the poem is anonymous, the author joins a long line of medical poets, including Samuel Garth (1660/1-1719), John Armstrong (1708/9-79) and Mark Akenside (1721-71), who displayed their 'ornamental' qualifications in verse, while also contributing to the discursive cultivation of improvement in the $S$ cots. ${ }^{80}$ Duncan, senior, himself was well known for his poetry, particularly within the sociable context of Edinburgh club culture, in which he played a leading role as the founder of the Aesculapian Society, the Harveian Society, the Gymnastic Society and the Royal Caledonian Horticultural Society, and as a member of numerous other medical and nonmedical clubs and societies. ${ }^{81}$ Famously, until the age of 82, Duncan climbed Arthur's Seat on the 1st of May each year and produced a poem inspired by his contemplations on the walk, and at least three of these poems were published in the Scots Magazine. In May 1817, a headpiece is included that explains their derivation:

Contemplations on ARTHUR'S SEAT, a high hill in the Neighbourhood of EDINBURGH, by a Gentleman far advanced in life, who has made it a rule to walk to the top of it, on the 1st of May annually, at an early hour; and, considering it as an altar, under the canopy of heaven, there to express his feelings for the moment in poetic language. ${ }^{82}$

One of these poems included in the May 1815 number is signed 'M. D. Septuagenarius', identifying the author as a medical man (even to those unaware of Duncan's idiosyncratic custom), and the closing stanza emphasizes the author's benevolence and selfless pursuit of moral rectitude, carrying forward the magazine's presentation of medical men as moral exemplars:

Teach me, with love of GOD and Man

Through fleeting life's uncertain span,

Contented with my lot,

To prise above all riches can,

A life without a blot. ${ }^{83}$ 
Poetry, as a genteel accomplishment, however, was just one means for medical practitioners to participate in the culture of 'medico-gentility' - to 'cultivate a reputation as leisured men of liberal education'. ${ }^{84}$ As Brown explains, they might also do so

through the pursuit of such "polite" and/or enlightened pursuits as agricultural improvement, botany, or antiquarianism. They might also seek to establish associations with local civic and country worthies and play an active role in a culture of public sociability through their involvement in local political or social clubs.

Brown emphasizes that 'one of the most important arenas for the elaboration of these identities was provided by local medical charitable institutions' ${ }^{85}$

Beyond the practical usefulness of the Scots Magazine for encouraging philanthropic giving towards the Edinburgh Lunatic Asylum, the extensive coverage of the campaign in the magazine brought Duncan and his collaborators further into public purview. 'Address to the Public, respecting the Establishment of a Lunatic Asylum at Edinburgh', in the November 1807 number, includes a list of 'Trustees, Managers, and office-bearers', with 'Dr Andrew Duncan, Sen.' heading up the list of the 'Medical Board'. ${ }^{86}$ 'Some Account of the Plan for establishing a Lunatic Asylum at Edinburgh', in the January 1808 number, credits Duncan, senior with first bringing forward a proposal for the asylum while president of the RCPE in 1792, and also includes his name, amongst numerous other medical men, in the 'List of Subscriptions for building a Lunatic Asylum at Edinburgh' ${ }^{87}$ As Guenter B. Risse argues in his study of charitable giving to the Edinburgh Royal Infirmary in the eighteenth century, 'gifts were never entirely disinterested, and individual donors had much to gain in moral reputation and social status'. Such charitable giving represented a Christian sensibility towards the plight of the less fortunate, as well as civic and patriotic devotion, and contributed to 'the establishment of urban elites identified by their piety and humanitarianism'. ${ }^{88}$ As such, Duncan's charitable giving identifies him (amongst others) as one of these 'urban elites', while his leadership of the campaign displays his 'medico-gentility', providing him the opportunity to (in his own words) exhibit his 'earnest desire to serve the cause of humanity, to promote the interest of my native country, and to wipe off what I have long considered as a national disgrace to the enlightened and flourishing kingdom of Scotland' ${ }^{89}$ What better context to promote such a cause (and an identity) than in a magazine that celebrated the moral and material achievements of Scottish medical men and that was dedicated from its offset to 'the PROSPERITY OF SCOTLAND'? ${ }^{90}$

In examining the run of the Scots Magazine from 1804 through 1817, a productive relationship between this popular periodical and Scottish medical culture becomes evident. The medical contents of the magazine (which also include extensive coverage of the debates surrounding vaccination and 
inoculation at this time) lack the polemical edge of the early reviews of medical texts in the second Edinburgh Review and the fresh hybridizing potential of Blackwood's literary experiments. However, the Scots maintained its own unique relationship with medical culture-one which was defined by a shared dedication to civic and national improvement across both periodical and medical cultures, particularly within the field of medical police, as well as by the ability of the magazine to act as a potent forum for expressing a dominant form of medical identity at this time-an identity that would soon come under threat as the nineteenth century progressed and new ideals of professionalism emerged. ${ }^{91}$

\section{Notes}

1 This work was supported by the Wellcome Trust [097597/Z/11/Z].

2 F. Macdonald, 'Medicine', in S. W. Brown and W. McDougall (eds.), The Edinburgh History of the Book in Scotland: Volume 2: Enlightenment and Expansion, 1707-1800 (Edinburgh: Edinburgh University Press, 2012), pp. 494-502, on p. 502.

3 I. Chalmers, U. Tröhler and J. Chalmers, 'Medical and Philosophical Commentaries and Its Successors', in J. Chalmers (ed.), Andrew Duncan Senior: Physician of the Enlightenment (Edinburgh: National Museums Scotland, 2010), pp. 36-55, on p. 37.

4 G. Dawson, R. Noakes and J. R. Topham, 'Introduction', in G. Cantor, G. Dawson, G. Gooday, R. Noakes, S. Shuttleworth and J. R. Topham (eds.), Science in the Nineteenth-Century Periodical, Reading the Magazine of Nature (Cambridge: Cambridge University Press, 2004), pp. 1-37, on p. 29. See also, L. Henson, G. Cantor, G. Dawson, R. Noakes, S. Shuttleworth and J. R. Topham (eds.), Culture and Science in Nineteenth-Century Media (Aldershot and Burlington: Ashgate, 2004); G. Cantor and S. Shuttleworth (eds.), Science Serialized: Representations of the Sciences in the Nineteenth-Century Periodicals (Cambridge, MA and London: MIT Press, 2004). For a bibliography of medical articles in nineteenth-century periodicals, see E. M. Palmegiano, Health and British Magazines in the Nineteenth Century (Lanham, MA: Scarecrow Press, 1998).

5 M. Coyer, 'Medical Discourse and Ideology in the Edinburgh Review: A Chaldean Exemplar', in A. Benchimol, R. Brown and D. Shuttleton (eds.), Before Blackwood's: Scottish Journalism in the Age of Enlightenment (London: Pickering \& Chatto, 2015), pp. 103-16, on p. 104.

6 M. Coyer, Literature and Medicine in the Nineteenth-Century Periodical Press: Blackwood's Edinburgh Magazine, 1817-1858 (Edinburgh: Edinburgh University Press, 2017), p. 1.

7 For example, medical culture is not discussed in M. Pittock (ed.), The Edinburgh Companion to Scottish Romanticism (Edinburgh: Edinburgh University Press, 2011).

8 For a concise overview of this scholarship, see P. Wood and C.W.J. Withers, 'Introduction: Science, Medicine and the Scottish Enlightenment: An Historiographical Overview', in C.W.J. Withers and P. Wood (eds.), Science and Medicine in the Scottish Enlightenment (East Linton: Tuckwell Press, 2002), pp. 1-16.

9 H. Cockburn, Memorials of his Time, 1779-1830 (Edinburgh: T. N. Foulis, 1910), p. 300; D. Stewart, 'The Death of Maggie Scott: Blackwood's, the Scots Magazine and Periodical Eras', in Before Blackwood's, pp. 117-28, on p. 121.

10 'Preface', Scots Magazine, 1 (January 1739), pp. i-iv, on pp. i, ii. 
11 A. Benchimol, 'For "the PROSPERITY OF SCOTLAND": Mediating National Improvement in the Scots Magazine, 1739-49', Studies in Scottish Literature, 39:1 (2013), pp. 82-103, on p. 84.

12 Stewart, 'The Death of Maggie Scott', p. 122.

13 Benchimol, 'For "the PROSPERITY OF SCOTLAND", p. 89.

14 D. S. M. Imrie, The Scots Magazine, 1739-1826: A Bicentenary Study (Originally Published in-“The Scots Magazine”, January-June 1939) [Edinburgh, 1939], p. 349.

15 'Suggestions for the Improvement of the Edinburgh Botanic Garden', Scots Magazine, 71(June 1809), pp. 404-7, on p. 404.

16 'National and Local Improvements. No. I', Scots Magazine, 76 (March 1814), pp. 186-90, on p. 186.

17 P. Borsay, 'The Culture of Improvement', in P. Langford (ed.), The Eighteenth Century, 1688-1815 (Oxford: Oxford University Press, 2002), pp. 183-210, on p. 184.

18 'The Observer. No. I', Scots Magazine, 71 (December 1809), pp. 905-8, on p. 907.

19 'Queries, Inquiries, and Hints', Scots Magazine, 66 (January 1804), pp. 17-19, on p. 17.

20 'On Rural Police as It Respects the Building of Villages', Scots Magazine, 66 (January 1804), pp. 19-23, on p. 19; 'On Rural Police.-(Continued from p. 23.)', Scots Magazine, 66 (February 1804), pp. 85-8, on p. 88.

21 'On Rural Police as it Respects the Building of Villages', pp. 20, 21.

22 'Female Schools for Cleanliness, Morals, and Decorum', Scots Magazine, 66 (March 1804), pp. 198-202, on p. 198.

23 'Female Schools for Cleanliness, Morals, and Decorum', p. 199. A satirical respondent to 'A Cleanly Scotsman' in May 1804 continues this narrative of the end of Enlightenment culture: '[T] he votaries of pleasure and fashion trouble not their heads, about any improvements, but such as may contribute to their immediate gratification.... A time indeed was, when the love of letters surpassed the love for good eating, and when the simplicity of manners, unencumbered with the refinements of fashion, permitted our philosophers and men of erudition to dedicate to private study those hours and talents which are now indispensably devoted to modern midnight entertainment. . . . Our modern men of erudition, new-modelled and improved by the natural progress of manners are now not only men of learning, but men of business and pleasure'. 'Academical Chairs, for Fashion and Luxurious Living, \&c. in the City of Edinburgh', Scots Magazine, 66 (May 1804), pp. 349-55, on pp. 349-50.

24 'Female Schools for Cleanliness, Morals, and Decorum', pp. 199, 198.

25 'On the Causes and Consequences of Inattention to Cleanliness', Scots Magazine, 66 (April 1804), pp. 243-6, on pp. 244, 246.

26 B. White, 'Training Medical Policemen: Forensic Medicine and Public Health in Nineteenth-Century Scotland', in M. Clark and C. Crawford (eds.), Legal Medicine in History (Cambridge: Cambridge University Press, 1994), pp. 145-64, on p. 149.

27 B. M. White, 'Medical Police, Politics and Police: The Fate of John Robertson', Medical History, 27 (1983), pp. 407-22, on p. 420.

28 'Female Schools for Cleanliness, Morals, and Decorum', p. 199. In this regard Edinburgh was catching up with Glasgow, which passed its own Police Act in 1800, out of similar concerns for public order after rapid industrialization. See: A. Benchimol, 'Let Scotland Flourish by the Printing of the Word: Commerce, Civic Enlightenment and National Improvement in the Glasgow Advertiser, 1783-1800' (Chapter 2, this volume).

29 M. McCrae, 'Andrew Duncan and the Health of Nations', Journal of the Royal College of Physicians of Edinburgh, 33 (2003), pp. 2-11, on p. 6. 
30 J. Chalmers, 'Medical Jurisprudence and Public Health: The Role of Andrew Duncan Junior', in J. Chalmers (ed.), Andrew Duncan Senior: Physician of the Enlightenment, pp. 100-13, on p. 103.

31 White, 'Training Medical Policemen', p. 149.

32 McCrae, 'Andrew Duncan and the Health of Nations', pp. 2, 7.

33 White, 'Training Medical Policemen', p. 146.

34 On the university chair, see M. H. Kaufman, 'Origin and History of the Regius Chair of Medical Jurisprudence and Medical Police established in the University of Edinburgh in 1807', Journal of Forensic and Legal Medicine, 14 (2007), pp. 121-30.

35 McCrae, 'Andrew Duncan and the Health of Nations', p. 9. In this, Duncan follows in the tradition of the voluntary hospital movement in Scotland. See G.

B. Risse, 'For God and Country: Duties and Rewards of Charity at the Edinburgh Infirmary', in New Medical Challenges During the Scottish Enlightenment (Amsterdam: Rodopi, 2005), pp. 19-65.

36 [A. Duncan, senior], 'A Short View of the Extent and Importance of Medical Jurisprudence, considered as a branch of education' (n.p., [1798]), p. 11. This attribution is based upon John Chalmer's bibliography in Andrew Duncan Senior: Physician of Enlightenment, p. 230.

37 White, 'Medical Police, Politics and Police', p. 409. For a discussion of public health in the age of Chadwick, see C. Hamlin, Public Health and Social Justice in the Age of Chadwick Britain, 1800-1854 (Cambridge: Cambridge University Press, 1998), and on Scotland's distinctive approach to public health, see C. Hamlin, 'William Pulteney Alison, the Scottish Philosophy, and the Making of a Political Medicine', Journal of the History of Medicine and Allied Sciences, 61.2 (2006), pp. 144-86; D. Hamilton, The Healers: A History of Medicine in Scotland (Edinburgh: Canongate, 1981), pp. 196-233; H. M. Dingwall, A History of Scottish Medicine (Edinburgh: Edinburgh University Press, 2003), pp. 164-208.

38 [Duncan, senior], 'A Short View of the Extent and Importance of Medical Jurisprudence, considered as a branch of education', pp. 8-9.

39 [Duncan, senior], 'A Short View of the Extent and Importance of Medical Jurisprudence, considered as a branch of education', p. 7. This phrase is echoed in 'Heads of Lectures on Medical Police. By Andrew Duncan, M.D. Professor of the Institutions of Medicine in the University of Edinburgh' (Edinburgh: Printed by Adam Neill and Co., 1801), p. 7.

40 Scots Magazine, 66 (April 1804), p. 272.

41 J. Chalmers, 'The Edinburgh Lunatic Asylum', in J. Chalmers (ed.), Andrew Duncan Senior: Physician of the Enlightenment, pp. 72-89, on pp. 74-5.

42 Chalmers, 'The Edinburgh Lunatic Asylum', p. 75.

43 'On the Necessity of a Public Lunatic Asylum in Edinburgh', Scots Magazine, 66 (April 1804), pp. 272-3, on p. 273.

44 'Female Schools for Cleanliness, Morals, and Decorum', p. 199.

45 'On the Necessity of a Public Lunatic Asylum in Edinburgh', p. 272.

46 'On the Establishment of a Lock Hospital in Edinburgh', Scots Magazine, 66 (April 1804), pp. 273-5, on p. 275.

47 'Hints of a Plan for Supporting the Royal Infirmary: To the Editor', Scots Magazine, 66 (November 1804), p. 833.

48 Chalmers, 'The Edinburgh Lunatic Asylum', p. 76.

49 Chalmers, 'The Edinburgh Lunatic Asylum', p. 76.

50 This text was 'Printed by James Ballantyne \& Co. and sold by Archibald Constable \& Co. Edinburgh; and by Constable, Hunter, Park, and Hunter, Booksellers, Ludgate-Hill, London'. 


\section{Megan Coyer}

51 'Review-Observations on Lunatic Hospitals', Scots Magazine, 72 (January 1810$)$, pp. 40-4, on p. 40.

52 'Description of the Plan of the Edinburgh Lunatic Asylum', Scots Magazine, 70 (March 1808), p. 163. The two illustrations featuring the engraved plans for the Edinburgh Lunatic Asylum are unpaginated.

53 'Description of the View', Scots Magazine, 66 (January 1804), p. 3.

54 L. Dixon, 'Scott, Robert (1777-1841)', Oxford Dictionary of National Biography, Oxford University Press, 2004, www.oxforddnb.com/view/article/24906 [accessed 26 September 2016].

55 According to the publication information, this text was 'Printed by Neill \& Co., and sold by A. Constable \& Co. and other Booksellers, for the Benefit of the Edinburgh Lunatic Asylum'.

56 R. Porter, 'Lay Medical Knowledge in the Eighteenth Century: The Evidence of the Gentleman's Magazine', Medical History, 29 (1985), pp. 138-68, on p. 154.

57 Gentleman's Magazine (February 1805), pp. 132-3, on p. 132.

58 'Observations Respecting Lunatic Asylums in Scotland', Scots Magazine, 72 (June 1810), pp. 445-9, on p. 445.

59 'View of the Institution at Edinburgh for the Relief of Incurables', Scots Magazine, 74 (April 1812), pp. 279-82, on p. 279 (my italics).

60 See, for example, L. Rosner, Medical Education in the Age of Improvement, Edinburgh Students and Apprentices, 1760-1826 (Edinburgh: Edinburgh University Press, 1991), p. 2.

61 'Biographical Account of Dr Buchan', Scots Magazine 67 (April 1805), pp. 2815, on p. 282; 'Biographical Account of the Late Mungo Park', Scots Magazine 67 (May 1815), pp. 339-44, on p. 339; and 'Suggestions for the Improvement of the Edinburgh Botanic Garden', p. 404.

62 'Remarkable Instance of the Benefits to be Derived from Patent Medicines', Scots Magazine, 69 (May 1807), pp. 329-32, on p. 330.

63 [J. P. Frank], 'Description of Edinburgh: With an Account of the Present State of Its Medical School. From the German of Frank', Scots Magazine, 70 (December 1808), pp. 907-10; [J. P. Frank], 'Description of Edinburgh: With an Account of the Present State of Its Medical School. From the German of Frank', Scots Magazine, 71 (January 1809), pp. 10-14; [J. P. Frank], 'Description of Edinburgh: With an Account of the Present State of Its Medical School. From the German of Frank', Scots Magazine, 71 (February 1809), pp. 94-8; [J. P. Frank], 'Description of Edinburgh: With an Account of the Present State of Its Medical School. From the German of Frank', Scots Magazine, 71 (April 1809), pp. 258-61; [J. P. Frank], 'Account of the Town and University of Glasgow. From the German of Frank', Scots Magazine, 71 (May 1809), pp. 333-5.

64 [J. P. Frank], 'Description of Edinburgh: With an Account of the Present State of Its Medical School. From the German of Frank', p. 908.

65 Porter, 'Lay Medical Knowledge in the Eighteenth Century', pp. 164, 165.

66 'On Biography', Scots Magazine, 66 (March 1804), pp. 163-8, on pp. 163, 164.

67 'On Biography', p. 165.

68 'On Biography', p. 166.

69 'Memoirs of the Late Dr Currie, of Liverpool', Scots Magazine, 67 (October 1805), pp. 749-52, on pp. 751-2, 750, 752.

70 'Memoirs of Dr James Anderson, Late Physician-General, Madras', Scots Magazine, 72 (March 1810), pp. 179-81, on p. 180.

71 'Biographical Account of the Late William Roxburgh, M.D.', Scots Magazine, 78 (April 1816), pp. 276-8, on p. 278.

72 'Memoirs of the Late Sir Andrew Balfour', Scots Magazine, 74 (June 1812), pp. 409-17, on p. 415. 
73 'Memoirs of the Late Sir Andrew Balfour', p. 411.

74 'Memoirs of the Late Sir Andrew Balfour', p. 414.

75 'Memoirs of the Late Sir Andrew Balfour', p. 417.

76 M. Brown, Performing Medicine: Medical Culture and Identity in Provincial England, c. 1760-1850 (Manchester and New York: Manchester University Press, 2011), p. 9.

77 M. J. Coyer and D. E. Shuttleton, 'Introduction: Scottish Medicine and Literary Culture, 1726-1832', in M. J. Coyer and D. E. Shuttleton (eds.), Scottish Medicine and Literary Culture, 1726-1832 (Amsterdam and New York: Rodopi, 2014), pp. 1-22, on pp. 4-5.

78 J. Gregory, 'Observations on the Duties and Offices of a Physician and on the Method of Prosecuting Enquiries in Philosophy', in L. B. Mccullough (ed.), John Gregory's Writings on Medical Ethics and Philosophy of Medicine (Dordrecht, Boston and London: Kluwer Academic Publishers, 1998), p. 98.

79 'Poetry - Lines to Dr Currie, On His Valuable Discoveries Relative to the Effect of Cold Water in Fevers', Scots Magazine, 67 (February 1805), p. 136.

80 On Armstrong, see A. Budd, John Armstrong's The Art of Preserving Health: Eighteenth-Century Sensibility in Practice (Burlington: Ashgate, 2011); on medical self-promotion through poetry more broadly, see D. Porter and R. Porter, Patient's Progress: Doctors and Doctoring in Eighteenth-Century England (Stanford, CA: Stanford University Press, 1989), particularly pp. 123-4.

81 On Duncan and club culture, see J. Chalmers, 'Medical Clubs and Societies'; J. A. Gray, 'The Royal Medical and Medico-Chirurgical Societies'; and J. Chalmers, 'Duncan's Non-Medical Clubs and Societies', in J. Chalmers (ed.), Andrew Duncan Senior: Physician of the Enlightenment, pp. 114-33, pp. 134-55, pp. 169-80. Michelle Faubert has argued that Duncan's poetry was a vital part of his medical identity as a reformer in the care of the mentally ill through his work for the Edinburgh Lunatic Asylum. See M. Faubert, Rhyming Reason: The Poetry of Romantic-Era Psychologists (London: Pickering \& Chatto, 2009), pp. 98-104.

82 [A. Duncan, senior], 'Poetry-Contemplations on ARTHUR'S SEAT', Scots Magazine, 79 (May 1817), p. 376. This is my own attribution.

83 [A. Duncan, senior], 'Contemplation on the top of ARTHUR'S SEAT, on the 1st of May 1815. By M.D. Septuagenarius', Scots Magazine, 77 (May 1815), p. 376. This is my own attribution.

84 M. Brown, 'Rethinking Early Nineteenth-Century Asylum Reform', The Historical Journal, 49 (2006), pp. 425-52, on p. 430.

85 Brown, 'Rethinking Early Nineteenth-Century Asylum Reform', p. 430.

86 'Address to the Public, respecting the Establishment of a Lunatic Asylum at Edinburgh', Scots Magazine, 67 (November 1807), pp. 817-20, on pp. 819, 820.

87 'Some Account of the Plan for establishing a Lunatic Asylum at Edinburgh', Scots Magazine, 68 (January 1808), pp. 9-11, on p. 11.

88 Risse, 'For God and Country', p. 24.

89 A. Duncan, senior, 'A Letter: Majesty's Sheriffs-Depute in Scotland, Recommending the Establishment of Four National Asylums for the Reception of Criminal and Pauper Lunatics. By Andrew Duncan Sen. M.D. \& P.' (Edinburgh: Printed by Patrick Neill, 1818), p. 3.

90 'Preface', pp. i-iv, on p. iv.

91 Following Brown's chronology, one can see initial signs of the demise of 'medicogentility' as a dominant form of medical identity within the Scots: within a biography of Dr William Buchan (1729-1805), a popular distrust of medical men with extra-professional pursuits is noted, as 'mankind in general conceive, and perhaps not unjustly, that the practice of such an important profession as 


\section{Megan Coyer}

that of medicine, is alone sufficient to occupy the mind of any one individual' ('Biographical Account of Dr Buchan', p. 283). A similar sentiment is expressed in Currie's biography in the magazine. For Blackwood's reaction against this popular distrust, see M. Coyer, 'Delta: The Construction of a NineteenthCentury Literary Surgeon', in Literature and Medicine in the Nineteenth-Century Periodical Press: Blackwood's Edinburgh Magazine: 1817-1858 (Edinburgh: Edinburgh University Press, 2017), pp. 88-123. Christopher Lawrence, however, argues that the culture of the gentleman physician was extant until at least the end of the nineteenth century. See C. Lawrence, 'Incommunicable Knowledge: Science, Technology and the Clinical Art in Britain 1850-1914', Journal of Contemporary History, 20.4 (1985), pp. 503-20. 